\section{ST. THOMAS'S HOSPITAL.}

The vacancy in the office of Physician to St. Thomas's Hospital, occasioned by the death of Dr. Henry Burton, has been filled up by the appointment of Dr. J. Risdon Bennett, one of the assistant physicians.

\section{SOCIETY OF APOTHECARIES.}

Gentlemen admitted Members on Thursday, Sept. 6th, 1849 :-Thos, Stokes Guppy, Sidbury, Devon; Philip Heary Tribe, Bristol; Richard Barwell, Norwich.

\section{OBITUARY.}

On the 26th ult., in Dublin, Cusach Roney, Esq., M.D., aged 69.

On the lst instant, at Stockwell, Surrey, after a few hours illness, Dr. James Leatham Clarke, surgeon, R.N., late of Her Majesty's ship Hydra, in his 4lst year.

On the 3rd instant, after a few hours' illness, Michael L. Mason, Esq., surgeon, 5, High Street, Newington, an old and much respected practitioner.

On the 4th instant, John Morgan, surgeon, Ordnance Hospital, Dover, late of Royal Artillery, aged 71.

On the 7 th instant, at Tipton, Staffordshire, Willis m John Power, surgeon, 91st Regiment, in the 37th year of his age.

On the 8th instant, in St. James's Square, Dr. Drever, M.D., aged 76.

On the 10th instant, in Dublin, after a few davs illness, Edward D. Tarleton, M.D., A.B., (T.C.D., aged 40, Physician to the Bath General Hospital.

\section{BOOKS RECEIVED.}

The Microscopic Anatomy of the Human Body in Health and Disease, illustrated by numerous drawings in colour. By Arthur Hill Hassall, M.B. London : Samuel Highley. Part XV.

Three Lectures. B.y F. Plombey, M.D., Ph.D., F.L.S. Maidstone : Hall and Sone.

Monthly Journal and Retrospect of the Medical Sciences, September, 1849.

London Journal of Medicine: a Monthly Review of the Medical Sciences., September, 1849.

On the Mode of Communication of Cholera. By John Snow, M.D. London : John Churchill.

\section{PROVINCIAL MEDICAL AND SURGICAI. ASSOCIATION.}

\section{THE APPOINTMENT OF EDITORS.}

To the Worcester Council of the Provincial Medical and Surgical Association.

Gentlemen, - I beg to inform you that the Committee of the Presidents and Vice-Presidents of this Association, appointed at the Anniversary Meeting, at Worcester, to fill up the vacancy occasioned in the office of editor, by the deatl of Dr. Streeten, have unanimouly appointed Dr. Ranking, of Norwich, and Mr. Walsh, of Worcester, conjoint editors of the Journal of the Association.

\section{CHARLES HASTINGS,}

President of the Association.

Worcester, September 8, 1849.

\section{SUFFOLK BRANCH.}

To the Members of the Suffolk Branch of the Provincial Medical and Surgical Association.

Mr. Bree, the Honorary Secretary, would feel obliged to those gentlemen in his Brauch, who have not paid their subscriptions for the current year, or who are in. arrears, to forward the amount to him, as he is making up his accounts for the year.

Mr. Bree takes this opportunity also of soliciting: subscriptions and donations to the Benevolent Fund. A subscription of five shillings from each member would make up the present great desideratum-i.e., the reserve permenent fund of $£ 2000$.

\section{NOTICE TO MEMBERS.}

The Secretary presents his compliments to thosemembers of the Provincial Medical and Surgical. Association whose Subscriptions remain in Arrear, and begs respectfully to cull their attention to the following Law, which was passed unanimously at the Anniversary Meeting, held at Bath, in 1848 :-

"If any Member's Subscription remain unpaid twelve months after it shall have become due, the Medical Journal aud other publications of the Society shall be withhela from such Member till his arrears be paid."

He earnestly entreats all those gentlemen whose Subscriptions are now in arrear, that they will cause them to be paid, either to himself, or to the Treasurer, Dr. Hastings, without further delay.

\section{JAMES P. SHEPPARD,}

Secretary to the Association.

Worcester, August 6th, 1849.

\section{ERRATA.}

The paper "On Aneurism of the Aorta," read by Dr. C. H. Kingdon, at Exeter, should have been stated as from E. P. Pridham, Esq.

In Dr. Durrant's paper, page 481, first column, line 57 , for "palpitation" read "palpation."

\section{TO CORRESPONDENTS.}

Labour in Hemiplegia.-Dr. Simpson, of Edinburgb, is engaged in some experiments on the expulsive action of the uterus, after division of the spinal cord. $\mathrm{He}$ is anxious to obtain notes of cases of labour, occurring in complication with hemiplegia, and also cases of anencephalous monsters. If any of our readers huve the means of complying with his wishes, by forwarding their notes to him, they will be doing a service to science, as well as conferring a favour upon the Professor.

The account of the meeting at Bangor arrived too late for insertion, it will appear in our next number.

Communications have been received from Mr. Roe, Mr. Humphry, Mr. Greenhow, Mr. Hawkes, Dr. Watmough, Mr. Lev, and Mr. Loyd.

It is requested that all letters and communications be sent to J. H. Walsh, Esq., Foregate Street, Worcester. Parcels and books for review may be addressed to the care of Mr. Churchill, Princes Street, Soho. 